\title{
The Perceptions of Saudi English Teachers about their Contribution to the Development of English Curriculum in Saudi Arabia
}

\author{
Lujain Jaza AlSehli ${ }^{1}$ \\ ${ }^{1}$ Yanbu University College, Saudi Arabia \\ Correspondence: Lujain Jaza AlSehli, Yanbu University College, Saudi Arabia. E-mail: lujainjaza1997@, \\ gmail.com
}

Received: April 15, 2020; Accepted: May 24, 2021; Published: May 25, 2021

\begin{abstract}
The current research investigated the perceptions of Saudi English teachers about their contribution to the development of English curriculum with the Ministry of Education (MOE). Also, this research sought to know the role of Saudi English teachers in developing English curriculum in Saudi Arabia. To obtain teachers' perceptions, an online questionnaire was designed via google forms with open and close-ended questions along with a Likert scale section. It was shared with the Saudi Faculty of English account on Twitter. The major cause of conducting this research was to raise the awareness of including Saudi English teachers in developing English curriculum, and to make this process as a collaborative effort among various stakeholders and English teachers. The findings indicated the absent role of Saudi teachers and the lack of their involvement in developing English curriculum in Saudi Arabia. Moreover, the results showed their willingness to participate and be part of this process.
\end{abstract}

Keywords: Saudi English teachers, Saudi Arabia, questionnaire, developing English curriculum

\section{Introduction}

In a world full of competition at all levels where every country wants to prove their best, Saudi Arabia is one of the countries that consistently is evolving. The Ministry of Education (MOE) in Saudi Arabia is a growing sector where everyday a decision is made. English curriculum development is one of the important jobs of the ministry. Saudis nowadays have a good proficiency level in English language because of the multicultural settings in this country and some job requirements. As claimed by Mullick (2013), English language could be recognized as a second language rather than a foreign language in the future of Saudi Arabia. Due to the 2030 vision, Mullick's claim could be true. The vision allows more varieties in business and tourism where foreigners' investments are increasing, and more of them are visiting Saudi Arabia. This emphasis on preparing a fully equipped generation with good communication skills. Which could start by building an excellent educational system. However, curriculum development is an exclusive process that controlled by the MOE where teachers are not involved.

\subsection{Statement of the Problem}

Curriculum development is extremely important in every educational system. It is an effort that needs to be done collaboratively among various stakeholders and teachers. In Saudi Arabia, the teacher's role is almost absent. This gap can create some problems such as some contradiction between what the teacher thinks to be taught, what the MOE thinks it is appropriate to be, and what is needed by learners where English curriculum development in Saudi Arabia lacks this collaboration. Crucially, teachers' participation in the development of English curriculum need to be discussed because they are the ones who interact directly with the students and know their capabilities, limitations, and needs.

\subsection{Purpose of the Study}

The purpose of this study was to investigate the perceptions of Saudi English teachers about their contribution to the development of English curriculum. Also, this study sought to know the role of Saudi English teachers in this process.

\subsection{Research Question}

This research sought to answer the following question:

What are the perceptions of Saudi English teachers about their contribution to the development of English curriculum? 


\section{Literature Review}

This section defines the key concept and reviews of the previous studies.

\subsection{Definitions of Key Concept}

\subsubsection{Curriculum Development}

Taylor (2001) defines curriculum development as an active process that includes every step in education from the learner's needs to the assessment and evaluation of the learning process. Also, it is not a rigid system. On the contrary, it is an adjustable system that concerns with the product and process of learning. Additionally, curriculum development concerns with the materials, syllabus, and methods of teaching as well as developing the objectives of courses (Calub, 2018). In the views of Mohanasundaram (2018), curriculum development is a system that aims to ameliorate the education sector in a country. Also, it is an ongoing process that can be affected by society's changes and the learners' needs.

\subsubsection{Previous Studies in the Literature}

One study was conducted by Mullick (2013) in Madinah, Saudi Arabia. He explored teachers' perceptions of English curriculum development in Saudi Arabia. The study involved five male native English speakers who lived in Saudi Arabia for ten years and taught English courses in the preparatory program at Taibah University. The participants had over five years of teaching experience in Saudi Arabia. All the participants took an administrative role in curriculum development where three of them had a master's degree in TESOL and two had a master's degree in curriculum. The tools were an open-ended questionnaire and semi-structured interviews conducted for 30 minutes. The results were analysed through narrative analysis. Mullick (2013) found three main themes in the results: (1) lack of teachers' voice, (2) oppression, (3) and the lack of teachers' enrolment in curriculum development. Although the participants had an administrative role in curriculum development, one of them said, "what is the point of having native English-speaking teachers when their ideas and suggestions are rejected." The participants expressed their disappointment where their opinions and views were not considered by the curriculum designers in Saudi Arabia. Also, the results showed that the procedure was only one-way transmission of the textbook and that they were recipients who applied it in their classrooms. As stated by the researcher, the controlling phenomena or the top-down approach in educational management is the reason for oppression where teachers' voices are kept within classrooms. The second study was conducted in Iran by Mellati and Khademi (2014) where they studied the learners' preferences and teachers' attitudes about English language materials used in Iran. The participants were native Iranian speakers, 200 students and 20 teachers with teaching experience ranged between five and fifteen years. All the participants were registered in general English courses. The participants were 90 males and 130 females. Their ages were between 20 and 60 years. They were from different specialties at the Islamic Azad University in Iran. The study followed mix-method research (qualitativequantitative). Two tools were used. A need analysis questionnaire was designed by the researchers which contained six parts of Yes/No questions and a Likert scale. The need analysis questionnaire involved the students' learning goals, skills of language such as speaking, listening, and writing. The results were analysed through the Statistical Package for Social Sciences (SPSS). As stated by Mellati and Khademi (2014), the results of the first tool were contradicted with course objectives. Most of the students' purpose of learning English was for fun and some for writing a good research paper. While all the material's goal was how to read and write English fluently. The researchers claimed that the gap between the learners' preferences and the course objectives led them to bad education and puts pressure on teachers who wanted to manage and help the students to reach their learning goals. After that, semi-structured interviews were performed to six teachers who participated earlier in the questionnaire for 30 minutes to reflect on their answers about their attitude toward the materials. The interviews were coded and analysed manually. The findings revealed the absence of teachers' role in English curriculum development. Also, teachers in the interviews asserted the importance of bringing authentic materials and cultural topics to develop students' intercultural competence. Mellati and Khademi (2014) found that teachers and curriculum designers can work together in designing books for specific language skills and courses for specific purposes, so they can help students to reach their learning goals.

The third study was conducted by Alnefaie (2016) in Makkah, Saudi Arabia. It investigated teachers' attitudes about their contribution in English curriculum design. Also, it aimed to raise the awareness of teachers' role in this regard. The study followed a qualitative research method with 30 minutes interviews. They were conducted with six Saudi male English teachers who work at public middle schools in Makkah. The participants had a teaching experience that varies between seven and sixteen years. The data collection procedure of the study followed the following steps: (a) the interviews were performed and recorded in Arabic, (b) they were transcribed in Arabic, and (c) they were read several times for meaning comprehension. Then, the researcher transcribed it in English 
with some quotes from the participants. According to Alnefaie (2016), the findings of the study revealed the marginalized status of teachers in English curriculum in Saudi Arabia. Also, their comments would not be considered as their valuable experiences in teaching were not appreciated. In addition, he stated that the MOE viewed teachers' role as tools for applying the books to the students in their classes. There were no chances given to them to suggest or participate in designing those books. The participants claimed that not giving chances for teachers to develop English books affected their teaching performance by relying on extra materials in the class. Moreover, the researcher highlighted one participant's situation which was holding a master's degree in curriculum and English language instructions. However, he did not have any opportunity in designing English books or take part in decision making with the ministry.

The fourth study was conducted in Turkey by Baş and Şentürk (2019). They studied the significance of teachers' participation in curriculum development. The researchers adopted the qualitative study design with semi-structured interviews for 30 minutes. They were conducted with 27 teachers working in five different high schools in Niğde, Turkey. Their teaching experiences varied between six and 11 years. Among the participants, 13 were females and 14 were males. The interviews were conducted in Turkish, then translated into English. The researchers analysed the interviews via content analysis and divide the answers into four categories: (1) participation opportunities in curriculum development, (2) roles and responsibilities in curriculum development, (3) impact on decision-making process, and (4) outcomes of their participation in curriculum development. According to the researchers, all the curriculum in Turkey is designed by the Ministry of National Education (MoNE). And there are some limited number of teachers working there. The findings revealed that almost all the teachers had the opportunity to participate in curriculum development indirectly via published forms given to them in schools or surveys in the ministry's website. However, teachers expressed that their roles and responsibilities in curriculum development process were not clear; they had no power to influence the decision-makers. As stated by Baş and Şentürk (2019), the only authority who can influence the curriculum development process is the MoNE. Besides, the teachers reflected on the outcomes of their participation negatively by stating that their suggestions and comments were not considered in the curriculum. They believed that their views were collected as a chore of the ministry and have been rejected. Baş and Şentürk (2019) claimed that the MoNE should appreciate teachers' experiences by considering their comments, suggestions, and giving them more positions on the ministry.

The current research shared some similarities and differences with the studies above. It shared with the two studies performed by Mullick (2013) and Alnefaie (2016) the country and purpose of the study, but it differs with the city, number of participants, and gender of participants. This study was conducted at Yanbu Industrial City, Saudi Arabia with 17 male and female participants. In addition, it differs from the study done by Mellati and Khademi (2014) where they included learners' preferences in English curriculum. This study aimed only to investigate the perceptions of Saudi English teachers about their contribution to the development of English curriculum. Also, their role in developing English curriculum. Additionally, this study is different from the studies above where no interviews were conducted with the participants, however, an online questionnaire was designed with open and close- ended questions along with a Likert scale which was shared with the Saudi Faculty of English account on Twitter.

\section{Methodology}

This section discusses the type of research, research tool, participants, and data collection procedure.

\subsection{Type of the Research}

The type of the research was mixed methods (qualitative-quantitative). The questionnaire was designed with open and close- ended questions along with a Likert scale section.

\subsection{Research Tool Questionnaire}

The questionnaire was designed via google forms with three sections. The first section contained six close-ended questions related to the demographics of the participants in relation to: (a) age, (b) gender, (c) place of residence, (d) level of education, (e) years of experience, and (f) level of teaching English: elementary level, intermediate/middle level, high/secondary level, university/college level. The second section of the questionnaire included Likert scale statements to know the participants' perceptions of contributing to the development of English curriculum in Saudi Arabia. Five possible answers were selected, (1) strongly disagree, (2) disagree, (3) neutral, (4) agree, (5) strongly agree. The third section contained two open-ended questions. The first one was about their role in developing English textbooks. The second one was related to their suggestions or comments about the importance of including English teachers in developing English curriculum in Saudi Arabia (see Appendix A). 


\subsection{Participants of the Research}

The participants of this research were Saudi male and female English teachers who teach English to EFL learners in Saudi Arabia. The expected number via Twitter was 50 participants, however, 17 participants have participated in the questionnaire.

\subsection{Data Collection Procedure}

First, the questionnaire was designed via google forms. Then, it was shared with the Saudi Faculty of English account on Twitter. After the data were gathered, the researcher had read the answers and analysed them individually and collectively.

\section{Results and Discussion}

In this section, the results from the questionnaire are presented and discussed.

\subsection{Questionnaire Results}

To answer the research question "What were the perceptions of Saudi English teachers about their contribution to the development of English curriculum?" The first section of the questionnaire was designed in relation to the demographics of the participants. The female presence in this research was dominant. Among the participants, 12 females participated along with five males. Their ages were between 30 to 40 years old. They were from different regions of Saudi Arabia. Six participants were from Riyadh, four from Yanbu, and one participant from Jeddah, Makkah, Aseer, Albaha, Bisha, Unizya and Tabuk each. Moreover, eight of them had a bachelor's degree and nine had a master's degree. Also, they vary with their teaching experiences as it is shown in figure 1.

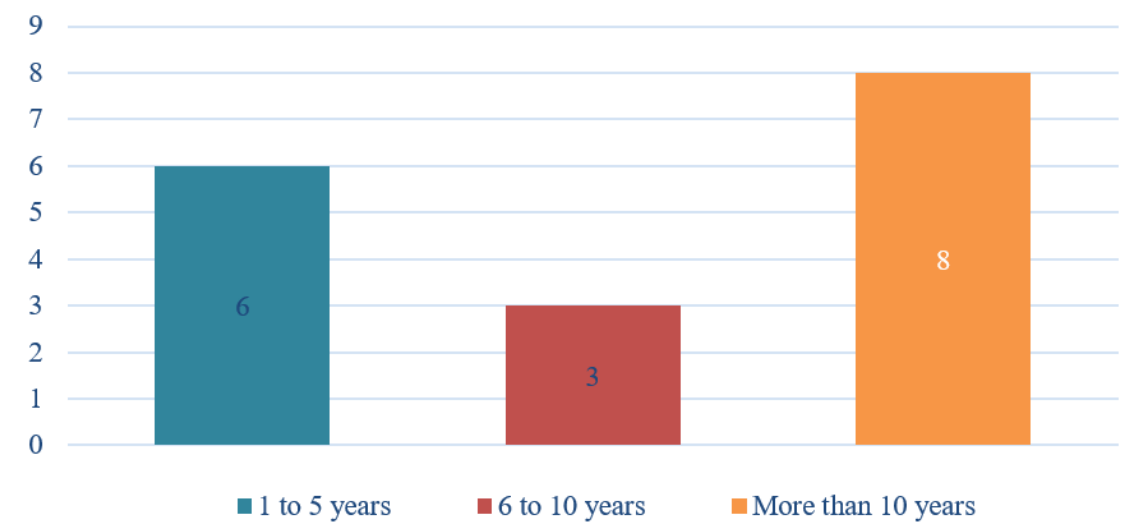

Figure 1. Years of experiences of the participating teachers

Additionally, one of the demographics questions was related to the level of teaching English language. The participating teachers had taught English language in different levels and some of them had experienced teaching English in more than one level. The data revealed that three teachers had the opportunity to teach English in all academic levels as the following: (1) elementary level, (2) intermediate level, (3) secondary level, and (4) university level. Also, three of them had taught English in secondary level only, and three of them had taught it in university level. Similarly, two teachers had taught English in elementary and intermediate levels, and other two had taught English in elementary, intermediate, and secondary level. Moreover, two teachers had taught English in secondary and college levels, and the last two teachers had taught English in elementary level only.

The second section of the questionnaire consisted of 5-point Likert scale statements to explore the participants' perceptions about their contribution to the development of English curriculum in Saudi Arabia.

\subsection{Discussion}

Table 1. Response's frequency and mean for Likert scale section

\begin{tabular}{llllllll}
\hline & Statements & SD & D & N & AG & SA & Mean \\
\hline 1 & I have participated in developing English books. & 3 & 8 & 2 & 4 & 0 & 2.4 \\
2 & $\begin{array}{l}\text { I believe that I have to be involved in developing } \\
\text { English curriculum in Saudi Arabia. }\end{array}$ & 0 & 1 & 3 & 9 & 4 & 3.9 \\
\end{tabular}




\begin{tabular}{llllllll}
\hline 3 & $\begin{array}{l}\text { I believe that my comments are considered when } \\
\text { developing English curriculum. }\end{array}$ & 5 & 7 & 4 & 0 & 2.8 \\
4 & $\begin{array}{l}\text { Teachers' feedback about the efficiency of the English } \\
\text { textbooks are collected. }\end{array}$ & 1 & 7 & 4 & 4 & 1 & 2.8
\end{tabular}

According to the above table, the participants had some common perceptions about their contribution to the development of English curriculum. The majority of them had disagreed and strongly disagreed with the first statement. Some participants did not have the opportunity to develop English textbooks. This is in complete agreement with the study done by Alnefaie (2016) where all the participants in his study had the same claim. Apart from this, they knew it is important for them to be involved in the curriculum development process where most of them agreed with the second statement forming the mean of (3.9). Interestingly, the third statement was a confusion to some of the participants. They were not sure about whether their comments are valued by the decision makers, and some participants completely disagreed with the third statement. This point has been discussed by Mullick (2013) where some teachers expressed their anger when they shared their comments, and they were not reflected on the English curriculum. In addition, seven participants disagreed with the last statement. This is also in consistent with Alnefaie (2016) where teachers explained their marginalizing status and their lack of voice in curriculum development. On the contrary, only four participants agreed with the last statement and this suggests that the efficiency of the English textbooks is a major concern of the ministry, and feedback is being asked, but some teachers might refuse to participate due to their belief that no matter what they have said, it would probably not be considered.

The third section of the questionnaire was designed with two open-ended questions. The first one was about teachers' role in developing English textbooks in Saudi Arabia. Table 2 illustrates some of the participants' responses to the first open-ended questions on the questionnaire.

Table 2. Some participants' responses to the first open-ended question

\begin{tabular}{|c|c|}
\hline \multicolumn{2}{|r|}{ Q.11 What is your role as an English teacher in developing English textbooks in Saudi Arabia? } \\
\hline Participant & "Focus on teaching skills and 21st century skills not only content of curriculum" \\
\hline \multicolumn{2}{|l|}{1} \\
\hline Participant & "Sending detailed feedback to the decision makers criticizing the English curriculum" \\
\hline \multicolumn{2}{|l|}{2} \\
\hline Participant & "Make sure that the books perfectly meet EFL Saudi students' learning needs and goals" \\
\hline \multicolumn{2}{|l|}{3} \\
\hline Participant & "Creating supplemental materials that corresponding to the English curriculum" \\
\hline \multicolumn{2}{|r|}{ ( } \\
\hline Participant & "Developing the books can be considered as the first step, however, it is not enough. There is \\
\hline 5 & a need to develop the teachers' teaching methods their classrooms' practices" \\
\hline
\end{tabular}

According to Table 2, the data suggested that the participants had different thoughts and perceptions about their role in developing English textbooks. The first theme among the participants' answers is their self-created solutions to make the English textbooks that they teach more efficient for their learners. In addition, one participant found that sending feedback is a major role regardless of the uncertain possibility to take it into consideration by the MOE. However, participant (5) claimed that teachers should be the ones who must be trained in order to deliver the content of the English textbooks efficiently. On the other hand, the second theme was found among the answers of the same above question is that few participants declared clearly that they had no role. One of them stated that by "I do not have any role." Also, another participant claimed, "I do not have the chance" and another participant shared his opinion by "I should have the chance to be heard when using the English textbooks." This theme is in constant with the study conducted by Alnefaie (2016) where all the teachers who participated in his study declared that they have no role in developing English textbooks or English curriculum in general. The last question was related to their comments or suggestions about the importance of including Saudi English teachers in developing English curriculum in Saudi Arabia. Table 3 illustrates some of the participants' responses to the second openended questions on the questionnaire. 
Table 3. Some participants' response to the second open question

\begin{tabular}{|c|c|}
\hline Participant & "Planning a curriculum structure should be a bottom- up process that includes all stakeholders \\
\hline & in the education programs including students too." \\
\hline $\begin{array}{l}\text { Participant } \\
2\end{array}$ & $\begin{array}{l}\text { "I think including English teachers would be beneficial because they are the ones who knew } \\
\text { more about students' needs. They work in the field and their comments and feedbacks would } \\
\text { more credible and realistic" }\end{array}$ \\
\hline $\begin{array}{l}\text { Participant } \\
3\end{array}$ & $\begin{array}{l}\text { "They have to choose different teachers from different regions and include them into } \\
\text { developing committee to hand the way." }\end{array}$ \\
\hline $\begin{array}{l}\text { Participant } \\
4\end{array}$ & $\begin{array}{l}\text { "More training should be involved in English teaching community. Also, to appreciate the good } \\
\text { worker and give them extra money. Furthermore, to expand the lessons in elementary stage. } \\
\text { Besides, we need English lap in schools." }\end{array}$ \\
\hline $\begin{array}{l}\text { Participant } \\
5\end{array}$ & $\begin{array}{l}\text { "It is important to help teacher how to deliver the curriculum effectively to master the goal of } \\
\text { learning English. In my opinion as an English teacher, English curriculum Developing is not } \\
\text { important as much as training teachers for delivering the curriculum." }\end{array}$ \\
\hline $\begin{array}{l}\text { Participant } \\
6\end{array}$ & $\begin{array}{l}\text { "There should be two-way communication in order to continuously consider feedback provided } \\
\text { by English teachers/faculty through different channels such as emails, seminars, discussion, } \\
\text { conferences...etc. English teachers/faculty should be always rewarded for their contribution to } \\
\text { the development of English curriculum" }\end{array}$ \\
\hline
\end{tabular}

According to Table 3, some important points were highlighted by the participants, for example, one of them stated that planning a curriculum should be a bottom- up process. This point concurs well with Mullick study in (2013) where he expressed the approach of educational system in Saudi Arabia as a top-down process where teacher's role is almost absent. In addition, three participants recommended that including Saudi English teachers in this process would make the English curriculum more relevant to the students' needs because they are the ones who are in daily contact with the students. Another participant suggested that in order to continuously consider the feedback provided by English teachers, there should be direct ways of communication between English teachers and the ministry. Also, three participants suggested that Saudi English teachers should be involved in the educational sector and in the English committee in the ministry in order to have a direct influence on designing and developing English textbooks. This point is directly in line with the study done by Baş and Şentürk in (2019) where the participants in their research asked for more positions in the ministry, so they can be part of developing English curriculum. On the contrary, only one participant suggested that developing English curriculum is not important as much as training teachers to deliver the curriculum more effectively.

\section{Conclusion}

In conclusion, this study investigated the perceptions of Saudi English teachers about their contribution to the development of English curriculum in Saudi Arabia. It also aimed to raise the awareness about the benefits of including Saudi teachers with the MOE in developing English curriculum. It is crucial to remember that everyone in this society is responsible to develop education. We as a Saudi community are lucky to have such a government that constantly work and develop every bit in this country. However, the participants of this study showed negative perceptions where they are not involved in developing English curriculum. Wooden (2014) asserted "do not let what you cannot do interfere with what you can do." This has resembled in the participants' effort when they developed their own solutions in their classrooms to level up the textbooks according to their students' needs and wants. Additionally, some participants indicated that they are willing to collaborate with the ministry and be part of this process. It is worth noting that there are hidden talents among Saudi English teachers that need to be appreciated and rewarded. After all, they are the active agents in this field.

\subsection{Limitations of the Study}

There are a number of limitations that could have influenced the results obtained of this study. First, the number of participants was too small; therefore, generalization cannot be made. Also, the tool used needed to be expanded by conducting interviews with the participants to explore their perceptions, but due to COVID-19 pandemic this was not an applicable option. 


\subsection{Recommendations}

Based on the results obtained, it is highly recommended to conduct more studies about the contribution of Saudi English teachers to the development of English curriculum with the MOE. Also, it is recommended for the MOE to consider the results of this study and the future studies that investigate teachers' role in curriculum development and to consider their opinions and comments.

\section{Acknowledgments}

First and foremost, thanks to Allah for making me strong enough to carry this research and make me even stronger to complete this journey successfully while having tough circumstances. Also, I would like to thank my beloved mother for her support, encouragement, and for believing in me. I am really grateful to have her in my life. Besides, I would like to express my gratitude to my supervisor Dr. Suzan AlDoubi for her constant feedback and for guiding me to carry out this research. Finally, I would like to thank my brothers and sisters for supporting me with their nice words. I hope one day I can return the favour to them and make them proud of me.

\section{References}

Alnefaie, S. k. (2016). Teachers' role in the development of EFL curriculum in Saudi Arabia: The marginalized status. Cogent education, 3(1), 1-14. https://doi.org/10.1080/2331186X.2016.1240008

Baş, G., \& Şentürk, C. (2019). Teachers' voice: Teacher participation in curriculum development process. Inquiry in education, 11(1), 1-31 Retrieved from https://digitalcommons.nl.edu/ie/vol11/iss 1/5/

Calub, C. L. (2018). Language curriculum development: An overview. Manuscript submitted for publication. Retrieved from https://www.researchgate.net/

Mellati, M., \& Khademi, M. (2014). ELT learners' preferences and teachers' attitudes: Determinant factors in curriculum design. International Journal of Language Learning and Applied Linguistics World, 5(3), 258273. Retrieved from https://www.researchgate.net/

Mohanasundaram, K. (2018). Curriculum design and development. Journal of applied and advanced research. 3(1), 4-6. https://doi.org/10.21839/jaar.2018.v3iS1.156

Mullick, H. (2013). Voices imprisoned within classrooms: A critical approach to curriculum development and teacher voice on a preparatory year English language program in the kingdom of Saudi Arabia. International Journal of Bilingual \& Multilingual Teachers of English, 1(02), 37-48. https://doi.org/10.12785/ijbmte/010201

Taylor, P. (2001). 10 Keys stages toward effective participatory curriculum development ( $2^{\text {nd }}$ edition). Gallen, Switzerland: Swiss association for international cooperation. Retrieved from https://www.participatorymethods.org/

Wooden. J. (2014). Thoughts of the day. W Michael scott word press. Retrieved from https://wmichaelscott.wordpress.com/2014/04/17/dont-let-what-you-cannot-do-interfere-with-what-youcan-do-john-wooden-2/

\section{Appendix A - Questionnaire}

Hello, my name is Lujan Jaza. I am a senior student at Yanbu University College majoring in Applied Linguistics. I am currently conducting my research project for a bachelor's degree. My research is about the perceptions of Saudi English teachers about their contribution to the development of English curriculum in Saudi Arabia. This questionnaire is a fundamental part of my research. I appreciate your time filling it with your answers since your opinion is really matters.

\section{Gender}
a) Female
b) Male

\section{Age}
a) $22-30$
b) $31-40$
c) Over 40

\section{Place of residence}


4. Qualification
a) Bachelor
b) Master
c) Doctorate

5.How many years have you been teaching English language?
a) 1 to 5 years
b) 6-10 years
c) Over 10 years

6.Which level have you been teaching English? (multiple answers when applicable)
a) Elementary level
b) Intermediate/middle level
c) High/ secondary level
d) University/college level

\section{*Likert scale*}

7. I have participated in developing English books
a) Strongly disagree
b) Disagree
c) Neutral
d) Agree
e) Strongly agree

8. I believe that I have to be involved in developing English curriculum in Saudi Arabia
a) Strongly disagree
b) Disagree
c) Neutral
d) Agree
e) Strongly agree

9. I believe that my comments are considered when developing English curriculum
a) Strongly disagree
b) Disagree
c) Neutral
d) Agree
e) Strongly agree

10. Teacher's feedback about the efficiency of the English textbook are collected
a) Strongly disagree
b) Disagree
c) Neutral
d) Agree
e) Strongly agree

11. What is your role as an English teacher in developing English books in Saudi Arabia?

12. Do you have any suggestions or comments about the importance of including English teachers in developing English curriculum in Saudi Arabia? 


\section{Copyrights}

Copyright for this article is retained by the author(s), with first publication rights granted to the journal.

This is an open-access article distributed under the terms and conditions of the Creative Commons Attribution license (http://creativecommons.org/licenses/by/4.0/). 